\title{
ECOLOGICAL ASPECTS OF WEED FLORA IN AN IRRIGATED RICE FIELD ECOSYSTEM AT BATHALAGODA IN SRI LANKA
}

\author{
C.N.B. BAMBARADENIYA ${ }^{* 1}$ and C.V.S. GUNATILLEKE ${ }^{2}$ \\ ${ }^{1}$ IUCN - The World Conservation Union, Sri Lanka Country Office \\ ${ }^{2}$ Department of Botany, University of Peradeniya, Peradeniya.
}

(Received: 26 October 2001 ; accepted: 06 August 2002)

\begin{abstract}
This study was carried out to document some ecological aspects of weeds in an irrigated rice field ecosystem in Bathalagoda, Sri Lanka. The study was conducted from November 1995 to August 1997 in two rice fields which differed in weed management practices. A total of 89 vascular plant species of rice-weeds belonging to 21 families, 31 genera of algae and three genera of macrofungi were recorded from the two rice fields surveyed. Among the dicotyledonous weeds recorded, one species (Elatine triandra Schkuhr.) is a new record for Sri Lanka. Of the weed flora recorded from the rice field ecosystem, 45 species were mesophytes, 41 species were hygrophytes, while three species were hydrophytes. The species composition of the weed flora was highest in the rice field bunds ( 82 species), while the rice field proper harboured 41 weed species, and 24 weed species occurred in the ditch habitat. In both rice fields, the temporal pattern of variation of weed species richness was similar. The weed species richness on the bunds differed according to the surface on which they occurred, and exhibited a clear spatial variation. The study also reflects the impacts of different weed management practices on the species diversity of weed flora in a rice field ecosystem.
\end{abstract}

Key Words: Biodiversity, rice fields, species richness, weed

\section{INTRODUCTION}

The rice field ecosystem harbours a rich composition of primary producers, which can be broadly grouped into two categories: the macrophytes and the microphytes. Besides the rice plant, the macrophytes include other rooted higher plants, which consist mainly of grasses, sedges and broad-leaved plants. These are generally referred to as weeds, as they compete with the rice plants for growth requirements such as space, nutrients and sunlight. ${ }^{9}$ The microphytes include the various types of algae and fungi. The weed communities occur in three different habitat types found in the rice field ecosystem: the field proper, the bund (levee) and the ditch (water supply canal) habitats. Each of these habitats contains a distinct weed community comprising several aquatic, wetland and dryland weeds. ${ }^{5}$ The rice field proper, which is the major habitat in the rice field ecosystem, remains under flooded conditions for a major period of a single rice cultivation cycle. The aquatic condition provides an extremely stable habitat for weeds resistant to excess water stress ${ }^{22}$ and for various groups of algae, which together constitute the photosynthetic aquatic

\footnotetext{
* Corresponding author
} 
biomass $(\mathrm{PAB})$ in rice fields. When the fields are drained prior to the harvesting of rice, dry conditions prevail, at which time terrestrial weeds colonise the field and become more conspicuous. Ditch habitats in the rice field ecosystem remain flooded during most parts of the year and many submerged, floating-leaved and free floating aquatic weeds are characteristic of these habitats. In contrast to the field proper and ditch habitats, the bunds remain under non-flooded, relatively dry conditions. Hence, the weed communities in the bunds consist mainly of terrestrial plants. ${ }^{5}$

Many ecological factors and crop production practices influence the species composition and abundance of the weed flora in the rice field ecosystem. ${ }^{18}$ Ecological factors which affect rice field weeds are mainly climatic and edaphic factors, including hydrology, soil type and moisture regime of rice fields, air and soil temperatures, and the composition of the seed populations in the soil. The cultivation practices which affect riceland weed communities include land preparation, method of crop establishment, crop rotation, fertilisation, method of weed control and the type of rice cultivars grown. ${ }^{14,18}$

Based on a survey of literature on rice field weeds reported from major rice growing countries, Moody ${ }^{13}$ has documented more than 1800 weed species occurring in the rice field ecosystems of Asia and South-East Asia alone. Species of Poaceae (grasses) are the most common, followed by Cyperaceae (sedges) and other broadleaved families respectively. The barnyard grass (Echinochloa crus-galli (L.) Beauv is considered to be the most troublesome weed of rice in the world, followed by $E$. colonum (L.) Link: ${ }^{18}$ Other rice field weeds of global importance include: grasses Eleusine indica, Ischaemum rugosum, sedges - Cyperus difformis, Cyperus rotundus, Cyperus iria, Fimbristylis miliaceae, broad-leaved - Monochoria vaginalis and Sphenochlea zeylanica. ${ }^{18}$ Several previous studies on the weed flora of rice fields in Sri Lanka highlight the rich diversity of weed species growing in the rice field agroecosystem. Velmurugu ${ }^{20}$ reported that there are about 70-80 common rice field weed species in Sri Lanka. Weerakoon and Gunewardena ${ }^{21}$ recorded 134 weed species belonging to 32 families from several rice fields in the three major climatic zones of Sri Lanka. Amerasinghe ${ }^{10}$ has recorded rice weeds in minor tank rice fields of the north-central dry zone of Sri Lanka. Chandrasena ${ }^{4,5}$ has studied the floristic composition and abundance of rice field weeds in major rice growing districts in the low-country wet zone of Sri Lanka. Chandrasena ${ }^{6}$ has also surveyed the rice weeds in the Kurunegala District - a major rice growing area in the intermediate zone of Sri Lanka. Seneviratne et $a l .{ }^{17}$ studied the fallow vegetation in rice fields of the lowland dry zone of Sri Lanka, where 19 species belonging to 10 families were recorded as fallow vegetation. A provisional list of weeds found in arable soils by Ameratunge $^{3}$ includes many species of major rice weeds. Based on most of the above surveys, Moody ${ }^{13}$ has listed approximately 340 weeds recorded from rice fields in Sri Lanka. 


\section{Specific objectives of the study on weed flora of rice fields}

The available literature on the rice field weed flora in Sri Lanka shows that most studies are related to the distribution and abundance of rice weeds, while information pertaining to their seasonal colonisation and succession in a rice field is scanty. The ecology of the weed flora in the rice field bunds has also not been adequately documented. Therefore, this study was carried out to meet the following specific objectives:

I To identify and document the weed flora (microphytes and macrophytes) in a rice field, their distribution and abundance in the field proper and bund habitats, and their succession during the rice cultivation cycle.

II To determine the temporal and spatial variation in the distribution and abundance of weeds in the field bunds, using qualitative diversity indices.

III To determine the temporal species richness of weeds in two selected rice fields with different weed management practices and observe the effects of weed management practices on the species richness of weeds.

\section{METHODS AND MATERIALS}

Study sites \& period of study

The study was carried out in two rice fields at Bathalagoda, in the Kurunegala district, located in the Intermediate Zone of Sri Lanka, $7^{\circ} 30^{\prime} \mathrm{N}, 80^{\circ} 280^{\prime} \mathrm{E}, 100 \mathrm{~m}$ a.s.l. Each rice field was approximately $0.4 \mathrm{ha}(1 \mathrm{acre})$ in extent and the two fields were approximately $2 \mathrm{~km}$ apart. Both fields were irrigated with water supplied by the neighbouring Bathalagoda tank. One rice field ('research field') was managed by the Rice Research and Development Institute (RRDI) at Bathalagoda, for the purpose of producing seed paddy under standard Integrated Pest Management (IPM) practices recommended by the Department of Agriculture. The other rice field ('farmer field') was maintained by a private farmer who cultivated rice on a commercial scale. Each field consisted of several plots (field proper - 'liyadde'), surrounded by bunds (levees). The two rice fields differed in weed management practices. Weed management practices were more intense in the research field, with application of herbicides, manual weeding, and slashing of field bunds both partially and intensively. In the farmer field, weeds in the field proper were removed manually, without the use of herbicides, while the bunds were slashed partially. Field sampling of the rice fields began in November 1995 and continued till August 1997, encompassing four consecutive rice cultivation cycles in both fields. Sampling was carried out at fortnightly intervals throughout the above study period. 
Collection, preservation and identification of the weed flora in the rice field: During the four cycles, weeds (macrophytes and microphytes) growing in the field proper, bunds and the water inlet (ditch) in the two rice fields were collected at fortnightly intervals for preparation of voucher specimens. The weeds, after being chemically treated with $70 \%$ alcohol, were placed in a plant press and left in a plant drier for 24-36 h. They were then mounted on herbarium sheets. Samples of microflora in water and top soil of the two rice fields were collected using a standard dipper, during the aquatic phase of each cycle. These were observed under a binocular stereo microscope and sorted into different groups. Algae were preserved and stored in 5\% formalin. The microphytes were identified upto the generic level, using keys of Abeywickrema ${ }^{1}$ and Abeywickrema et $a .^{2}{ }^{2}$ The macrophytic weeds were identified up to species level, using the keys of Chandrasena, ${ }^{7}$ Soerjani et $a l^{19}$ and Dassanayake and Fosberg. ${ }^{8}$ The voucher specimens were also compared with herbarium specimens at the Department of Botany, University of Peradeniya and at the National Herbarium of the Royal Botanical Gardens at Peradeniya. The provisional identifications were confirmed by an authority at the National Herbarium.

Sampling of rice field weeds: During the Maha 1995 and Yala 1996 cycles, the weed species richness in the rice field proper and the bunds in the research field and the farmer field were monitored at fortnightly intervals. On each sampling day, the number of weed species in four random plots $\left(1 \mathrm{~m}^{2}\right.$ each) in the middle of each liyadde and at four random $1 \mathrm{~m}$ length portions along the field bunds were counted. Weed management practices carried out were also noted.

A bund aligned across the flow of water consisted of three surfaces; a flat upper surface, a shallow lateral surface on the upper side of the bund and a deep angular lateral surface on the lower side of the bund. A bund aligned parallel to the flow of water consisted only of a flat surface and two shallow lateral surfaces on either side. As a clear difference in the composition of weed flora was observed on the three different surfaces in the first bund category, the bund weed flora in the research field was further evaluated during the Maha 1996 and Yala 1997 cycles. Three replicate sites (1.5 m in length) of this bund category were selected for monitoring, commencing from the field preparation stage at which time the bunds are completely cleared of weeds. The breadth of each bund surface monitored was measured. The soil moisture content (\%) of each surface was measured on three occasions, at early, mid and later stages of the crop cycle, by taking random soil core samples. The weed cover at the three sampling sites in the bund were left unslashed until the completion of each rice cultivation cycle.

During both cycles studied, the occurrence and relative abundance of each weed species was also determined about 95 days after transplanting (DAT), when each bund surface was fully covered with weeds. A strip quadrat $(100 \mathrm{~cm} \times 25 \mathrm{~cm})$ was placed on each of the bund surfaces of the three study bunds and the relative abundance of each weed species was scored on a scale of $1-5$ as follows: $1=$ Rare; $2=$ 
Occasional; 3 = Moderate; 4 = Common; 5 = Abundant. The scores 1,2,3,4 and 5 correspond to a visual cover estimation of $<10 \%, 11-25 \%, 26-40 \%, 41-70 \%$ and $>71 \%$ respectively of the strip quadrat for each species.

Data analyses: Using the qualitative data on the total number of weed species in the field proper and bunds during the Maha 1995 and Yala 1996 cycles, the temporal variation of the species richness of macrophytes in the field proper and bunds was represented graphically using mean species richness $\left(\mathrm{N}_{0}\right)$ values. The mean species richness of weeds in the field proper and the bunds in the research and farmer fields was statistically compared using the GLM procedure of the SAS system.

Using the qualitative data on the occurrence of different weed species in the three bund surfaces during the Maha 1996 and Yala 1997 cycles, the $\beta-$ (differentiation) diversity of weeds in each bund surface, and the degree of association or similarity of pairs of bund surfaces based on weed composition, were determined using Whittaker's measure $\left(\beta_{w}\right)$ and Jaccard index $\left(C_{j}\right)$ respectively, as described in Magurran; ${ }^{12}$

$\beta$ diversity: $\beta_{\mathrm{w}}=\mathrm{S} \alpha-1$, where $\mathrm{S}=$ total number of species, and $\alpha=$ mean species richness.

Species similarity: $\mathrm{C}_{\mathrm{j}}=\mathrm{j} /(\mathrm{a}+\mathrm{b}-\mathrm{j})$, where $\mathrm{j}=$ the number of species found in both sites, $\mathrm{a}=$ number of species in site $\mathrm{A}$, and $\mathrm{b}=$ number of species in site $\mathrm{B}$.

The above two indices are widely used to express the variation in species composition, using qualitative species data. ${ }^{12}$

\section{RESULTS}

\section{Floristic composition of rice field weeds}

A total of 89 species of rice-weeds (macrophytes) belonging to 21 families, 31 genera of microphytes (algae, under 4 phyla) and three genera of macrofungi were recorded from the two rice fields surveyed. Appendix 1 provides a comprehensive list of the species of rice weeds recorded, with information on their occurrence in major habitats of the rice field ecosystem , their life-cycle and life forms. Appendix 2 gives a list of algae and macrofungi recorded. Of the total weed species recorded, 42 were monocotyledons (in five families), 45 were dicotyledons (in 14 families), while two species were pteridophytes (under two families). The monocotyledons were dominated by grasses (Family: Poaceae - 21 species), followed by sedges (Cyperaceae - 14 species). Among the dicotyledons recorded, the Family Asteraceae had the highest number of species (11 species) followed by Scrophulariaceae (07 species). Among the dicotyledonous weeds recorded, one species (Elatine triandra Schkuhr.) is a new record for Sri Lanka. 
A high proportion (65\%) of the weed species recorded were annuals. The species composition of the weed flora was highest in the rice field bunds ( 82 species), where 36 species were exclusive to it and 27 of these exclusive species were dicotyledons (Table 1). The rice field proper harboured 41 weed species with five species confined to this habitat. Twenty four weed species occurred in the ditch (water inflow canal), with none being exclusive to it. Of the weeds that occurred in the rice field proper, Echinochloa colonum, Isachne globosa, Ischaemum rugosum, Cyperus haspan, Fimbristylis miliaceae, Marsilia quadrifolia, and Elatine triandra were the most abundant species during all the rice cultivation cycles. Of the species recorded from bunds, the dominant species included the monocotyledons Echinochloa colonum, Panicum repens, Cyperus rotundus, Fimbristylis miliaceae, Cyperus iria, and Commelina diffusa, and the dicotyledons Ageratum conyzoides and Lindernia rotundifolia and the fern Marsilia quadrifolia. Several species of cosmopolitan, terrestrial dicotyledonous weed species occurred in the field bunds and these included Ageratum conyzoides, Vernonia cinerea, Euphorbia hirta, Mimosa pudica, Urena lobata, Sida rhombifolia, Emilia sonchifolia, Tridax procumbens and Mikania cordata. Species of Axonopus and Commelina showed a dense and widespread growth along the ditch habitat.

Of the weed flora recorded from the rice field ecosystem , 45 species $(50.5 \%)$ were mesophytes (species which grow well in dryland conditions), 41 species (46\%) were hygrophytes (species which grow well in water saturated conditions) while three species ( $3.5 \%$ ) were hydrophytes (weeds growing well in submerged conditions). Compared to the weeds in the field proper and ditch habitats, the weeds on the bunds exhibited a wide variety of life-forms, which included erect, ascending, tufted, tillering, stoloniferous, rhizomatous, creeping, prostrate and climbing forms.

The algae included blue-green algae (BGA, Phylum Cyanophyta - 8 genera), green algae (Chlorophyta - filamentous forms - 1 genus; flagellated forms - 3 genera; non-flagellated, non-motile desmids - 15 genera), Euglenophytes - 2 genera, and diatoms (Bacillariophyta - 2 genera). The abundant genera of algae included: cyanophytes - Oscillatoria and Aphanothece; chlorophytes - Spirogyra, Closterium, Micrasterias, Pleurotaenium and Pediastrum; euglenophytes - Euglena; Diatoms Navicula. The macrofungi were recorded from the fallow fields with decaying vegetation, during the rainy seasons.

\section{Seasonal colonisation and succession of weed flora}

Succession in the field proper: The general pattern of colonisation and succession of flora in the rice field ecosystem was similar during each cycle. At the beginning of each rice cultivation cycle, practices associated with the preparation of fields (ploughing, puddling and tillage) resulted in the complete destruction of the fallow vegetation in the field proper and bunds. Within 2-3 days of flooding the fields, rich populations of unicellular green algae, dominated by phytoflagellates such as 
Euglena, Phacus, Chlamydomonas, Volvox and Gonium and diatoms such as Navicula appeared in the floodwater surface as green mats. These were soon followed (3-5 days after flooding) by epibenthic filamentous algae, including Spirogyra and Oscillatoria which formed dense mats on the floodwater surface during midday. Solitary and colonial desmids and non-mucilaginous cyanophytes also occurred at the same time. Monochoria vaginalis and Marsilia quadrifolia were the first aquatic macrophytes to appear within the first week of transplanting. These were followed by monocot weeds such as Ischaemum rugosum, I. timorense, Isachne globosa, Cyperus haspan, Fimbristylis miliaceae and Echinochloa spp. and the dicot species Sphenoclea zeylanica which emerged during the $2^{\text {nd }}$ and $3^{\text {rd }}$ weeks after transplanting. Other monocots such as Cyperus iria, C. difformis and dicots such as Ludwigia spp., and Elatine triandra appeared within 3-4 weeks of transplanting. A considerable change in the composition and abundance of floodwater microflora was clearly evident towards the mid aquatic phase (about 7 weeks after transplanting), where the filamentous algae became absent or scarce, while dense colonies of mucilaginous blue-green-algae consisting of Aphanothece spp. and Aphanocapsa spp. appeared.

Table 1: Distribution of the weed flora in the different habitats of the rice field.

( $\mathrm{m}=$ Monocotyledons; $\mathrm{d}=$ Dicotyledons; $\mathrm{p}=$ Pteridophytes $)$

(Values indicate the total number of species)

\begin{tabular}{lcccc}
\hline Location & Bund & Field & Ditch & Total \\
\hline Bund only & $36(10 \mathrm{~m}, 26 \mathrm{~d})$ & - & - & $36(10 \mathrm{~m}, 26 \mathrm{~d})$ \\
Field only & - & $5(2 \mathrm{~m}, 2 \mathrm{~d}, 1 \mathrm{p})$ & - & $5(2 \mathrm{~m}, 2 \mathrm{~d}, 1 \mathrm{p})$ \\
Ditch only & - & - & - & - \\
Field and Bund & $24(14 \mathrm{~m}, 10 \mathrm{~d})$ & $24(14 \mathrm{~m}, 10 \mathrm{~d})$ & - & $24(14 \mathrm{~m}, 10 \mathrm{~d})$ \\
Bund and Ditch & $12(8 \mathrm{~m}, 4 \mathrm{~d})$ & - & $12(8 \mathrm{~m}, 4 \mathrm{~d})$ & $12(8 \mathrm{~m}, 4 \mathrm{~d})$ \\
Field and Ditch & - & $2(2 \mathrm{~m})$ & $2(2 \mathrm{~m})$ & $2(2 \mathrm{~m})$ \\
Field, Bund \& Ditch10 $(6 \mathrm{~m}, 3 \mathrm{~d}, 1 \mathrm{p})$ & $10(6 \mathrm{~m}, 3 \mathrm{~d}, 1 \mathrm{p})$ & $10(6 \mathrm{~m}, 3 \mathrm{~d}, 1 \mathrm{p})$ & $10(6 \mathrm{~m}, 3 \mathrm{~d}, 1 \mathrm{p})$ \\
Total Species & $82(38 \mathrm{~m}, 43 \mathrm{~d}, 1 \mathrm{p})$ & $41(24 \mathrm{~m}, 15 \mathrm{~d}, 2 \mathrm{p})$ & $24(16 \mathrm{~m}, 7 \mathrm{~d}, 1 \mathrm{p}) 89(42 \mathrm{~m}, 45 \mathrm{~d}, 2 \mathrm{p})$ \\
\hline
\end{tabular}

When the fields were drained during the mature stage of the crop, hygrophytic weeds such as Monochoria vaginalis and Elatine triandra as well as hydrophytic weeds such as Lindernia spp., Ludwigia spp., Cyperus haspan C. iria, C. difformis, Echinochloa spp., and Ischaemum spp., started to die off gradually. Mesophytic weeds in the field bunds started to invade the drying fields. After the crop was harvested, mesophytic grasses (Panicum repens, Cyanodon dactylon), sedges (Cyperus rotundus, Kyllinga spp.)' and dicots (Eclipta prostrata, Sphaeranthus indicus, Desmodium spp., Euphorbia spp.) which were previously inhibited by the 
floodwater, started to germinate and rapidly colonise the dry fallow fields.

Succession on bunds: The first species to appear on the bunds following clean weeding were Marsilia quadrifolia and sedges including Cyperus spp. and Fimbristylis miliaceae, within a week of transplanting. About two weeks after transplanting, numerous species of hygrophytic and mesophytic monocot and dicot weeds started to emerge on the bund surfaces. All the bund surfaces were completely covered by weeds at approximately 12 weeks after transplanting. At this time, the flat bund surface was dominated by grasses (Cyanodon dactylon, Eragrostis unioloides and Panicum repens), sedges (Cyperus rotundus, Pycreus polystachyos) and Commelina spp. The shallow bund surface was dominated by Fimbristylis miliaceae, while the deep bund surface was dominated by many species of mesophytic dicots which were mainly erect forms.

\section{Effect of weed management practices on the richness and succession of weed species}

The seasonal succession of weeds in relation to agronomic practices was clearly evident when the temporal variation of the mean weed species richness in the field proper (spp. $/ \mathrm{m}^{2}$ ) and bunds (spp./m) was considered in the research and farmer rice fields, during two consecutive cycles, Maha 1995 and Yala 1996 (Fig. 1). In both fields, the temporal pattern of variation of weed species richness was similar during the two consecutive cycles. The mean weed species richness in the field proper and bunds showed a gradual increase after transplanting, and reached a stable level at approximately 90 days after transplanting. Draining of fields at the mature stage of the crop and subsequent drying of fields resulted in a slight decline in the weed species richness in the field proper, but increased during the fallow period. Weed species richness in the bund habitat started to decline after the mature stage of the crop, when most annual weeds entered the senescent phase. The weed species richness in the field proper and bunds was affected by weed control practices. The weed species richness declined with the application of herbicides (in the research field only), manual weeding (both in the research and farmer fields), and slashing of weeds in the bunds. Fertiliser inputs resulted in a rapid proliferation of individual weed populations in the field proper and on the shallow surface of the bunds.

Based on the data gathered during the Maha 1995 and Yala 1996 cycles, the mean weed species richness in the field proper of the farmer field was significantly higher $(\mathrm{P}<0.05)$ than that of the research field (Table 2). However, the mean weed species richness in the bunds of the two fields was not significantly different $(P>0.05)$. In both rice fields, the mean weed species richness in the field proper as well as on the field bunds between the two consecutive cycles (Maha 1995 and Yala 1996) was not significantly different $(\mathrm{P}>0.05)$. 


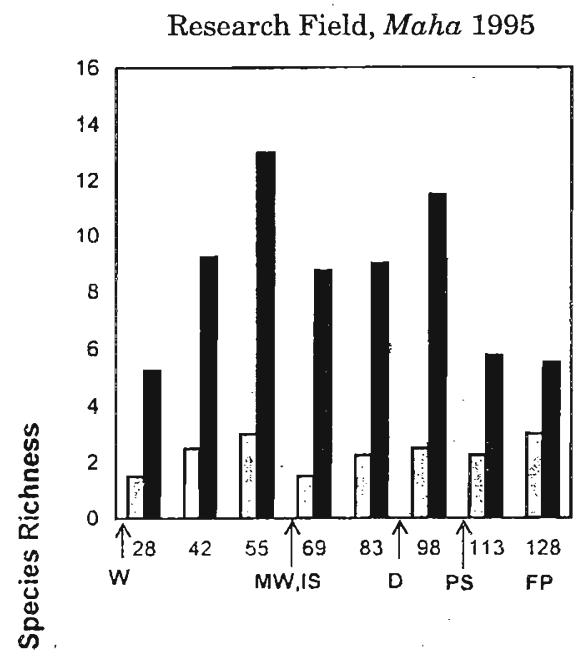

Farmer Field, Maha 1995

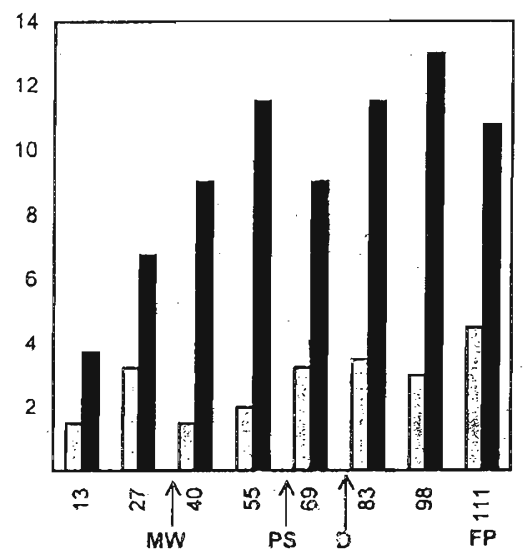

Research Field, Yala 1996

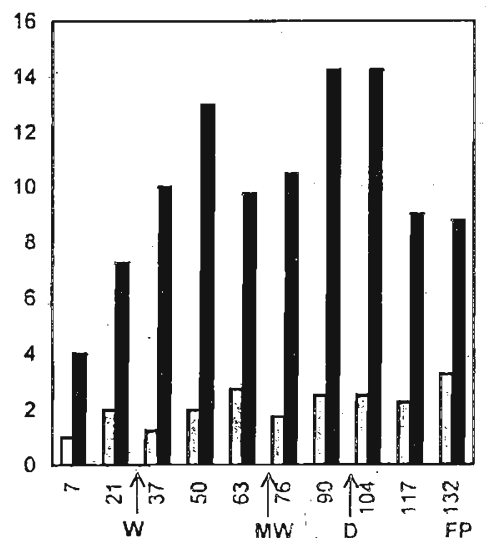

Farmer Field, Yala 1996

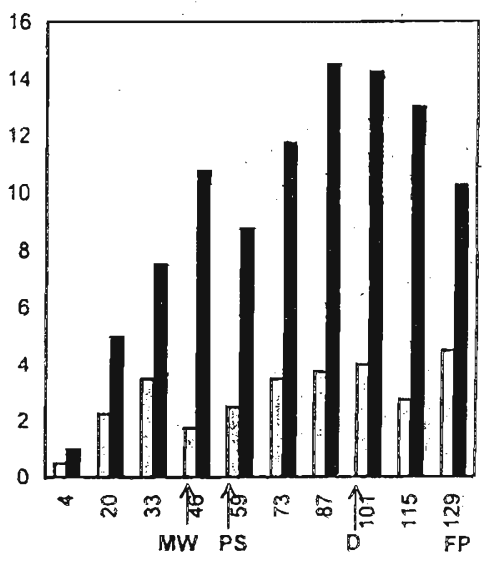

Days after transplanting

Figure 1: Temporal variation of weed species richness in the field proper (grey) and field bunds (black) of the research field and farmer field, during the Maha 1995 and Yala 1996 cycles.

W- Weedicide application; MW- Manual weeding; PS - Partial slashing

IS- Intense slashing; D- Draining of fields; FP- Fallow period

\section{Distribution of weeds in the three bund surface types}

The flat, shallow and deep surfaces of a bund differed in breadth, soil moisture content (\%) and light regine (Table 3). The shallow bund surface had the highest soil moisture content and the lowest breadth, while the effect of shading by the growing rice canopy was also high, resulting in a low light regime compared to the shallow and deep bund surfaces. 
Table 2: Mean weed species richness in the field proper and bund habitats in the two fields, during the Maha 1995 (October 1995 - February 1996) and Yala 1996 (April - August 1996) cycles.

\begin{tabular}{lcc}
\hline Site & Field proper $\left(\mathrm{spp} . / \mathrm{m}^{2}\right)$ & Field bunds $(\mathrm{spp} . / \mathrm{m})$ \\
\hline Research field & $\mathbf{2 . 2 0 ~ B}$ & $\mathbf{9 . 2 0 ~ A}$ \\
Maha 1995 & $2.31 \mathrm{a}$ & $8.50 \mathrm{a}$ \\
Yala 1996 & $2.12 \mathrm{a}$ & $9.02 \mathrm{a}$ \\
Farmer field & $\mathbf{2 . 8 6 \mathbf { A }}$ & $\mathbf{9 . 5 5} \mathbf{A}$ \\
Maha 1995 & $2.81 \mathrm{a}$ & $9.40 \mathrm{a}$ \\
Yala 1996 & $2.90 \mathrm{a}$ & $9.67 \mathrm{a}$ \\
\hline
\end{tabular}

Duncan grouping: Means (vertically) with the same letter (upper case: between fields, lower case: between cycles) are not significantly different

Table 3: Physical features associated with the three bund surface types.

\begin{tabular}{lccc}
\hline Feature & Shallow surface & Flat surface & Deep surface \\
\hline Breadth $(\mathrm{m})$ & $0.25 \pm 0.03$ & $0.32 \pm 0.05$ & $0.95 \pm 0.09$ \\
Soil moisture content $(\%)$ & & & \\
$\quad$ Aquatic phase: & $48.4 \pm 6.97$ & $29.6 \pm 6.57$ & $24.8 \pm 3.47$ \\
$\quad$ Dry phase: & $18 \pm 1.38$ & $12.5 \pm 1.58$ & $10.9 \pm 2.48$ \\
Light regime & Low & moderate & high \\
\hline
\end{tabular}

The weed species that were present in the three bund surface types during Maha 1996 and Yala 1997 seasons at 90 days after transplanting, and their relative abundance (score) are presented in Appendix 3. Weed species varied in occurrence and commonness in the three bund surface types and the general appearance of weeds in the three bund surfaces is shown in Fig. 2. Moreover, based on the presence of different weed species in the three bund surface types, 3 distinct distribution categories were identified (Table 4). The first category included 15 weed species (species Nos.1-15 in Appendix 3) which were distributed in all three bund types, and included 11 monocots and 4 dicots. The second category included weed species that occurred in any twro bund surface types only (11 species, Nos. 16-26 in Appendix 3 ). The 3rd category included weed species that were restricted to one bund type only (15 species, Nos.27-41 in Appendix 3). Interestingly, species in this last category were found only in the shallow and deep bund surfaces, and surprisingly 11 of the species were restricted to the deep bund surface. 


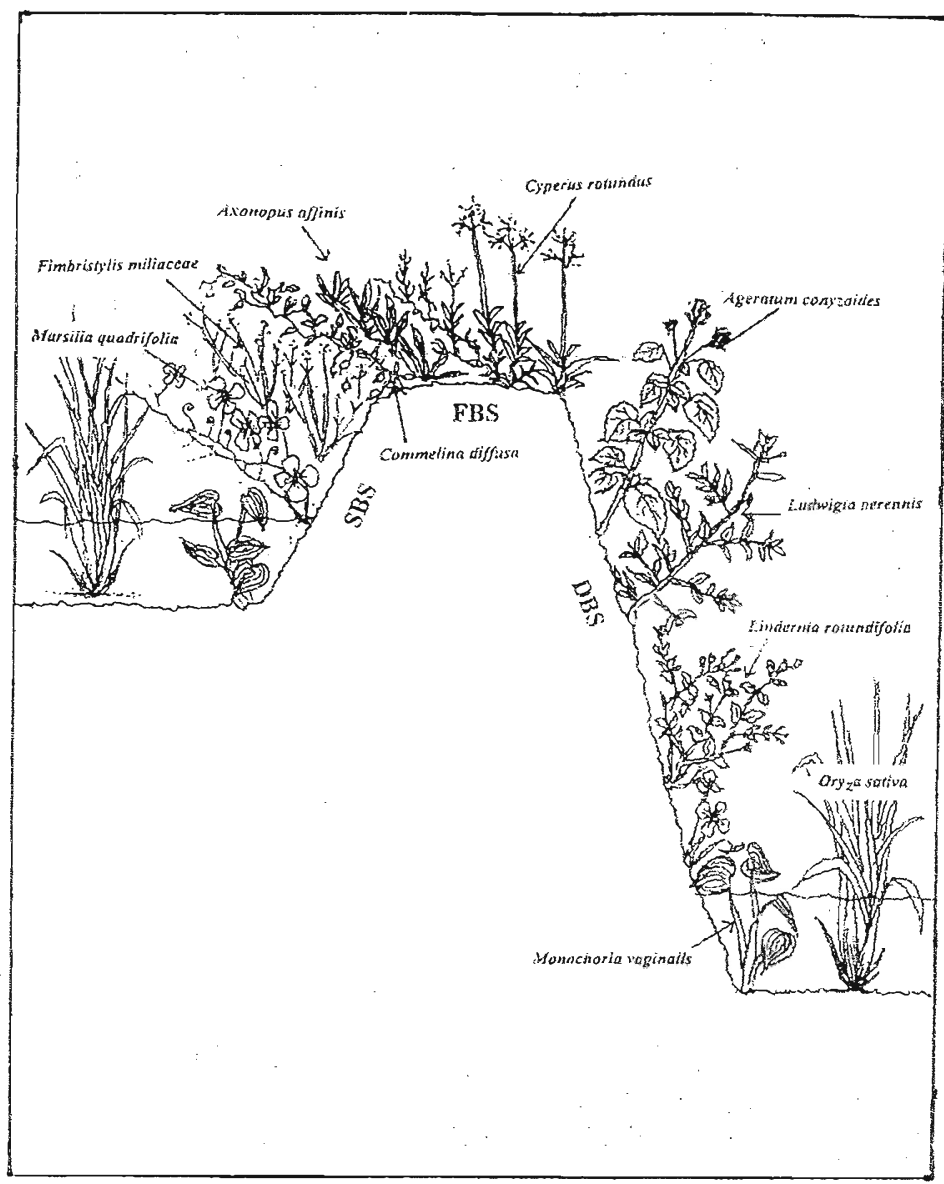

Figure 2: A diagram showing the general appearance and distribution of weeds on the different bund surface types in a rice field (FBS - Flat surface; SBF - Shallow surface; DBS - Deep surface).

The $\beta$-diversity of weed species occurring in the three bund surfaces during the Maha 1996 and Yala 1997 cycles was assessed at three spatial levels, viz., between similar surface types, between different surfaces and between bunds as a whole (Table 5). As indicated in Table 5 , the $\beta$-diversity values increased from the $1^{\text {st }}$ level of assessment (between similar surfaces) to the $3^{\text {rd }}$ level of assessment (among bunds), while the temporal variation at each of the above levels was approximately similar during the two consecutive cycles. The $\beta$-diversity in the shallow bund surfaces showed a higher variation compared to those in the flat and deep bund surfaces. At the next level, $\beta$-diversity of the shallow and deep bund surfaces showed the highest variation. The variation of weed species among the bunds ( $3^{\text {rd }}$ level) was slightly higher during the Maha 1996 cycle, than that during the Yala 1997 cycle. Based on similarity coefficients (Table 6), the weed communities in the shallow and deep bund surfaces were the least similar, while those in the flat and shallow bund surfaces 
were the most similar. The general trend as well as the values of the similarity coefficients was relatively similar during the two consecutive cycles.

Table 4 : Distribution of weed species in the three bund surfaces (Values indicate the total number of species)

\begin{tabular}{lcccc}
\hline Category & Flat & Shallow & Deep & Total \\
\hline 1. Common to all bund surfaces & 15 & 15 & 15 & 15 \\
2. Common to any two surfaces & & & & \\
a. Flat and shallow bunds & 3 & 3 & - & 3 \\
b. Shallow and deep bunds & - & 4 & 4 & 4 \\
c. Flat and deep bunds & 4 & - & 4 & 4 \\
3. Restricted to one surface only & & & & \\
a. Flat bund only & - & - & - & - \\
b. Shallow bund only & - & 4 & - & 4 \\
c. Deep bund oriy & - & - & 11 & 11 \\
Total & 22 & 26 & 34 & 41 \\
\hline
\end{tabular}

Table 5: Spatial and temporal variation of weed species occurring in the three bund surface types during the Maha 1996 and Yala 1997 cycles, at 90 DAT, based on $\beta$-diversity values using Whittaker's measure $\left(\beta_{w}\right)$.

Cycle

Source of Variation
Maha 1996

$\alpha$

$\beta_{\mathrm{w}}$

S

$\alpha$

$\beta_{\mathrm{w}}$

1. Between similar surfaces

$\begin{array}{lllllll}\text { Flat surface } & 19 & 12.66 & 0.50 & 19 & 11.33 & 0.67 \\ \text { Shallow surface } & 23 & 10.66 & 1.15 & 22 & 12.33 & 0.78 \\ \text { Deep surface } & 34 & 20.66 & 0.64 & 30 & 17.66 & 0.69\end{array}$

2. Between different surfaces

\begin{tabular}{ccccccc} 
Flat vs. Shallow & 26 & 11.66 & 1.23 & 26 & 11.83 & 1.19 \\
Shallow vs. Deep & 40 & 15.66 & 1.55 & 36 & 15.66 & 1.40 \\
Flat vs. Deep & 36 & 16.66 & 1.16 & 33 & 14.50 & 1.27 \\
3. Among bunds & 41 & 14.66 & 1.79 & 36 & 13.77 & 1.61 \\
\hline
\end{tabular}

( $\mathrm{S}=$ total no. of species; $\alpha=$ average no. of species) 
Table 6: Similarity among the three bund surface types based on weed composition (Similarity coefficients using Jaccard index- $\mathrm{C}_{j}$ ), during the Maha 1996 and Yala 1997 cycles, at 90 DAT).

Weed composition in bunds

Weed species common to FB \& SB

Similarity Coefficient $(\mathrm{Cj})$

Weed species common to FB \& DB

Similarity Coefficient $(\mathrm{Cj})$

Weed species common to SB \& DB

Similarity Coefficient $(\mathrm{Cj})$
Maha 1996

16

16

0.61

0.61

17

16

0.47

0.48

17

16

0.42

0.44

FB: Flat bund; SB: Shallow bund; DB: Deep bund.

\section{DISCUSSION}

The changing ecological conditions associated with the rice field ecosystem enables a rich weed flora to colonise the rice fields and complete their life cycle during a single rice cultivation season. During the early stages of a rice cycle, the flooded rice fields are dominated by a rich composition of microflora and wetland macrophytes, while dryland weeds replace wetland weeds during the later dry stages, including the fallow period. These events of seasonal colonisation and succession of rice field flora occur in a regular manner during successive rice cultivation cycles.

The seasonal succession of microflora in the flooded rice fields observed during this study was similar to those documented by previous workers. ${ }^{11,15}$ Similar to the observations made by Weerakone and Gunawardena, ${ }^{21}$ Poaceae and Cyperaceae constituted the major component of the macrophytic flora in this study. The abundant macrophytic weeds recorded during the present study from a rice field in the intermediate zone of Sri Lanka, and previous records of rice weeds from the wet $z^{2} e^{5}$ and dry zone of Sri Lanka (Amarasinghe ${ }^{10}$ ), indicate that the composition of the most abundant weeds is quite similar in rice fields throughout the island. Of the most abundant macrophytic weeds recorded during the present study, Fimbristylis miliaceae, Isachne globosa and Cyperus haspan were previously documented as the most serious rice field weeds throughout Sri Lanka, ${ }^{21}$ while Ischaemum rugosum was previously recorded as the most dominant weed in the Kurunegala district. ${ }^{6}$ Of the weeds recorded from the bunds, although Paspalum commersonii and Cyperus pilosus were previously recorded to be among the commonest monocotyledonous weeds found in the wet zone of Sri Lanka, 4,5 these two species were found to be occasional species during the present study. The cosmopolitan dicots recorded in the field bunds during this study had been previously 
documented by Chandrasena ${ }^{6}$ as well, from rice fields throughout the Kurunegala district, and were considered as opportunistic species which have invaded the rice agroecosystem. The dicotyledonous weed species (Elatine triandra) recorded for the first time in Sri Lanka has previously been documented as a common rice field weed in Indonesia. ${ }^{19}$

The significant differences in the mean species richness of weeds in the research and farmer fields could be attributed to the differences in weed management and water management practices associated with the two fields. In the research field, weeds in the field proper were removed manually and chemically (with a herbicide), and the supply of irrigation water was regular, resulting in the maintenance of a higher water depth. In the farmer field, weeds were removed only manually and the supply of water was irregular, resulting in a lower depth of water. Hence, the environmental conditions in the farmer field were more conducive for the emergence and prevalence of a higher number of weed species in the field proper, compared to the research field. Chandrasena ${ }^{5}$ too had observed that the composition of weed flora in rice fields depended on the amount of standing water in the fields. The management of weed cover in the bunds also differed in the two fields. In the research field, weeds in bunds were slashed partially as well as intensively, on two occasions per cycle. In the farmer field, weeds in bunds were slashed only partially, mostly once during a cycle. However, the absence of a significant difference in the mean species richness of weeds on bunds of the two fields, in spite of the differences in slashing methods, indicates that slashing of weeds mainly reduces the cover of weeds, and not their species richness.

Rice field bunds serve as an important habitat for a variety of weeds, acting as a reservoir for their seeds as well. The differences in the distribution and abundance of weeds in the different bund surface types show that weed species vary in their ecological amplitudes. Weed species that occurred in all three bund surface types are those which have a wide ecological amplitude and can be considered as generalist species, inhabiting many different microhabitats. At the other extreme, species which were restricted to only one bund surface type are possibly specialists, with a narrow ecological amplitude. It was also evident that the distribution of some weed species (eg. Leptochloa chinensis, Murdania spirata, Eclipta prostrata) were different during the Yala and Maha cycles, where they were restricted during one cycle and were common during the subsequent cycle, and vice versa. However, whether these species differ in their distribution and abundance between the Yala and Maha cycles in a given rice field has to be confirmed by further studies.

As indicated by the higher $\beta$-diversity values, the higher differentiation of the composition of weeds within the shallow bund surface could be attributed to the diurnal and seasonal fluctuations of the floodwater level, causing temporal and spatial differences in soil moisture content, and hence affecting the germination of weeds. In addition, the temporal and spatial changes of the weed composition in the 
shallow bund surface may also be influenced by the higher shading effect by the growing rice canopy and the disturbance to the soil caused by the burrows and tunnels of rats and crabs. The lower similarity of the weed compositions in the deep and shallow bund surfaces could be attributed to the marked differences in surface area, soil moisture content and light regimes associated with the above bund surfaces.

In conclusion, the study shows that a rich composition of micro and macro flora are associated with the irrigated rice field ecosystem. The macrophytes were dominated by grasses and sedges. These floral communities exhibited a uniform pattern of seasonal colonisation and succession during a rice cultivation cycle, in relation to the growth of the rice crop and agronomic practices carried out. A difference in the species richness of weeds in relation to weed management and water management practices was clearly evident. The weed communities in the field bunds, while being rich in species, showed a differential distribution both spatially and temporally in different bund surfaces, in relation to soil moisture, surface area and light regimes associated with each bund surface. This study contributed towards the understanding of certain aspects related to the general ecology of the weed flora associated with the rice field ecosystem.

\section{Acknowledgement}

This study forms part of a larger study on the ecology and biodiversity in an irrigated rice field ecosystem, funded by the National Science Foundation, Sri Lanka. We wish to sincerely thank the following: Dr. L. Nugaliyadde, Entomologist at the Rice Research and Development Institute, Bathalagoda, for making available the field sites for this study; Mr. M. M. Faizal, a private farmer in Bathalagoda, for permitting us to carry out part of this research in his rice fields; Dr. Cyril Wijesundera, Director - National Botanical Gardens, Peradeniya for confirming the identifications of macrophytes; Mr. Asanga S.T.B. Wijetunge - technical staff member of the Department of Botany, University of Peradeniya and Mrs. R.W. Edirisinghe, Agricultural Instructor at the National Herbarium, Peradeniya, for assisting us in the identification of rice field weeds. A special note of thanks goes to Mr. Thushara Ranasinghe for all the assistance given to us in the field and laboratory work. 


\section{Appendix 1: Floristic composition of rice field weeds, their life cycle, occurrence, habit and life-form.}

An=Annual; Pe=Perennial

b $\mathrm{F}=$ Field; $\mathrm{B}=\mathrm{Bund}$; $\mathrm{D}=\mathrm{Ditch}$ (Water supply canal)

c $\mathrm{A}=\mathrm{Abundant;} \mathrm{M}=$ Moderate; $\mathrm{O}=$ Occasional; $\mathrm{R}=\mathrm{Rare}$

d Hydro= Hydrophytic; Hygro = Hygrophytic; Meso= Mesophytic

e Er=Erect; As= Ascending; $\mathrm{Pr}=$ Prostrate; $\mathrm{Cr}=$ Creeping; $\mathrm{Rh}=$ Rhizomatous, $\mathrm{St}=\mathrm{Stoloniferous;}$

$\mathrm{Tu}=$ Tufted; Ti=Tillering; $\mathrm{Cl}=$ Climber; $\mathrm{H}=\mathrm{Herb} ; \mathrm{S}=$ Shrub; $\mathrm{Fl}=$ Free-Floating; Em= Emergent; Sub = Submersed

Group/Family!

Species
Life cycle Major habitat $^{\mathrm{b}} \&$ Habit $^{\mathrm{d}}$

Life-form ${ }^{\mathrm{e}}$ (Occurrence) $)^{c}$

Monocotyledons

Poaceae

Axonopus affinis Chase

A. compressus (Sw.) Beauv.

An (Pe)

Chloris barbata

Cyanodon dactylon (L.)

An

$\mathrm{Pe}$

$$
\mathrm{B}(\mathrm{O}), \mathrm{D}(\mathrm{A})
$$

$\mathrm{B}(\mathrm{O}), \mathrm{D}(\mathrm{A})$

Dactyloctaenium aegyptium (L.) Richt.An (Pe)

Digitaria ciliaris Schumach.

D. longiflora (Retz) Pers.

Echinochloa colonum (L.) Link

E. crus-galli (L.) Beauv

E. stagnina (Retz.) Beauv.

Eleusine indica (L.) Gaerth.

Eragrostis unioloides (Retz.)

Nees ex Steud

Isachne globosa (Thunb.) Kuntze

Ischaemum rugosum Salisb.

I. timorense Kunth

Leptochloa chinensis (L.) Nees

Leersia hexandra Sw.

Paspalum conjugatum Berg.

P. commersonii Lam.

Panicum repens $\mathrm{L}$.

Setaria geniculata (Lam.) Beauv.
An

An

An

An

An

An

An

An

An

An

An $(\mathrm{Pe})$

$\mathrm{Pe}$

$\mathrm{Pe}$

$\mathrm{Pe}$

$\mathrm{Pe}$

An
$\mathrm{B}(\mathrm{O})$

$\mathrm{F}(\mathrm{O}), \mathrm{B}(\mathrm{M})$

$\mathrm{F}(\mathrm{O}), \mathrm{B}(\mathrm{M})$

$\mathrm{B}(\mathrm{O})$

$\mathrm{B}(\mathrm{O})$.

F,B (A),D (O)

F,B (M)

$\mathrm{F}, \mathrm{B}(\mathrm{O})$

$\mathrm{B}(\mathrm{M})$

$\mathrm{B}(\mathrm{M})$

F (A),B,D (M).

$\mathrm{F}(\mathrm{A}), \mathrm{B}(\mathrm{M})$

F,B (O)

$\mathrm{F}, \mathrm{B}(\mathrm{O})$

$\mathrm{F}, \mathrm{B}, \mathrm{D}(\mathrm{O})$

$\mathrm{B}(\mathrm{O})$

F,B (O)

$\mathrm{B}(\mathrm{A})$

B ( R )
Meso

Meso

Meso

Meso

Meso

Meso

Meso

Hygro

Hygro

Hygro

Meso

Meso

Hygro

Hygro

Hygro

Meso

Hygro Er-As, Cr,Tu, Rh

Meso Er,Tu,Cr,St

Hygro Er,Tu,Cr,St

Meso Er-As,Rh

Meso

Er-As

Cyperaceae

Cyperus rotundus $\mathrm{L}$.
C. iria $\mathrm{L}$.
C. difformis $\mathrm{L}$.
C. pilosus Vahl

$\mathrm{Pe}$

$\mathrm{B}(\mathrm{A})$

An

An

$\mathrm{Pe}$
$\mathrm{F}, \mathrm{B}(\mathrm{M})$

$\mathrm{F} ;(\mathrm{M}), \mathrm{B}, \mathrm{D}(\mathrm{O})$

$\mathrm{F}, \mathrm{B}(\mathrm{M})$
Meso

Hygro

Er,Rh,St

Hygro

Er,Tu

$\mathrm{Er}, \mathrm{Ti}$

Hygro Er,Tu, Rh,St 
Appendix 1 contd.

Group/Family/

Species

C. tenuispica Steud

C. haspan L.

Fimbristylis miliaceae (L.) Vahl

F. dichotoma (L.) Vahl

F. schoenoides (Retz.) Vahl

Kyllinga brevifolia Rottboell

K. nemoralis (J.R. \& G.Forst)

Dandy ex Hutchins.

Pycreus polystachyos (Rotboell)

Beauv

P. pumilus (L.)

Schoenoplectus juncoides (Roxb.)

Palla

Commelinaceae

Commelina diffusa Burm.f.

C. benghalensis $\mathrm{L}$.

Cyanotis axillaris (L.) Sweet

Murdania spirata (L.) Bruckner
Life cycle ${ }^{\mathrm{a}} \mathrm{M}$

Major habitat ${ }^{b} \&$
(Occurrence) $^{c}$

$\begin{array}{cccc}\text { An }(\mathrm{Pe}) & \mathrm{F}(\mathrm{O}) & \text { Hygro } & \text { Er,Tu } \\ \text { Pe } & \text { F (A), B (M) } & \text { Hygro } & \text { Er, Tu, Rh } \\ \text { An } & \text { F,B (A) } & \text { Hygro } & \text { Er,Tu,Ti } \\ \text { An } & \text { F,B (M) } & \text { Hygro } & \text { Er-As,Tu } \\ \text { An(Pe) } & \text { F (O), B (R) } & \text { Hygro } & \text { Er,Tu } \\ \text { An(Pe) } & \text { B,D (O) } & \text { Meso } & \text { Er,Rh } \\ \text { Pe } & \text { B,D (O) } & \text { Meso } & \text { Er,Tu,Rh }\end{array}$

$\mathrm{An}(\mathrm{Pe})$

An

An
F,B (O)

$\mathrm{F}, \mathrm{B}(\mathrm{O})$

F,B (O)
Habit $^{\grave{d}}$

Life-form"

Hygro Er,Ti,Rh

Hygro Er,Tu

Hygro Er,Tu,Ti

Pontederiaceae

Eichhornia crassipes (Mart.) Solms An

$\mathrm{F}(\mathrm{R}), \mathrm{D}(\mathrm{O})$

Hydro

Fl,St

Monochoria vaginalis (Burm.f.) PreslAn

$\mathrm{F}, \mathrm{B}(\mathrm{M}) ; \mathrm{D}(\mathrm{O})$

Hygro

Em,Ti

Eriocaulaceae

Eriocaulon thwaitsii Koern.

An

$F(\mathrm{M})$

Hygro

Tu,Em

Dicotyledons

Asteraceae

Epaltes divaricata (L.)

Tridax procumbens L.

Ageratum conyzoides L.

Eclipta prostrata (L.) L

Eleutheranthera ruderalis

An

$\mathrm{B}(\mathrm{O})$

Meso

$\mathrm{H}, \mathrm{Er}$.

An

$\mathrm{B}(\mathrm{O})$

Meso

H,Er-As

An

$\mathrm{B}(\mathrm{A})$

Meso

$\mathrm{H}, \mathbb{E r}-\mathrm{As}$

An

$\mathrm{F}(\mathrm{O}), \mathrm{B}(\mathrm{M})$

Meso

H, Er-Pr

(Swartz) Sch. Bip

Eupatorium odoratum L.

An

$\mathrm{B}(\mathrm{M})$

Meso

$\mathrm{H}, \mathrm{Er}-\mathrm{As}$

Emilia sonchifolia (L.) DC

An

$\mathrm{B}(\mathrm{O})$

Meso

$\mathrm{S}, \mathrm{Er}$

An

Mikania cordata (Burm) Robinson An

$\mathrm{B}(\mathrm{O})$

Meso

$\mathrm{H}, \mathrm{Er}$

$\mathrm{B}(\mathrm{O})$

Meso

Cl

Spilanthes iabadicensis A. H. MooreAn

$\mathrm{B}(\mathrm{M})$

Meso

$\mathrm{H}, \mathrm{Er}$ 
Appendix 1 contd.

Group/Family/

Species
Life cycle Major habitat $^{\mathrm{b}}$ \& (Occurrence) $^{c}$
Sphaeranthus indicus L.

Vernonia cinerea (L.) Less

Scrophulariaceae

Dopatorium junceum (Roxb.)

Buch.-Ham.ex Benth.

Lindernia rotundifolia (L.) Alston An

L. anagallis (Burm.f.) Pennell

L. pusilla (Willd.)Boldingh

L. antipoda (L.) Alston

L. crustacea (L.)F.Muell

L. hyssopioides (L) Haines

Malvaceae

Abutilon asiaticum L.

Sida rhombifolia L.

Urena lobata L.

Onagraceae

Ludwigia decurrens Walt.

L. perennis $\mathrm{L}$.

L. hyssopifolia (G.Don) Exell

Fabaceae

Desmodium triflorum (L.) DCH, $\mathrm{Pe}$ Alyssicarpus vaginalis DC.

Cassia tora $\mathrm{L}$.

An

$\mathrm{An}(\mathrm{Pe})$

Euphorbeaceae

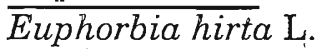

E.hypericifolia L.

E. rubicunda L.

E. indica Lam.

Phyllanthus debilis Klein

ex Willd.

Convolvulaceae

Ipomoea aquatica Forsk.

I. triloba $\mathbb{L}$.

An

An

An

An

Er

$\mathrm{H}$,
$\mathrm{F}(\mathrm{R}), \mathrm{B}(\mathrm{O})$

$\mathrm{B}(\mathrm{M})$

$\mathrm{F}(\mathrm{M})$

Hygro

H,Em, Sub

F,B (M); D(R ) Hygro

$\mathrm{B}(\mathrm{M}) ; \mathrm{D}(\mathrm{O})$ Hygro

$\mathrm{F}, \mathrm{B}(0)$

Hygro

$\mathrm{B}(\mathrm{M}) ; \mathrm{D}(\mathrm{O})$

$\mathrm{F}, \mathrm{B}(\mathrm{M})$

Hygro

Hygro

$\mathrm{F}, \mathrm{B}(\mathrm{O})$

Hygro

$\mathrm{H}, \mathrm{Cr}, \mathrm{Er}$

$\mathrm{H}, \mathrm{As}-\mathrm{Pr}$

H, Er-Pr

$\mathrm{H}$, Er-Cr

$\mathrm{H}, \mathrm{Er}-\mathrm{Pr}$

$\mathrm{H}, \mathrm{Er}-\mathrm{Pr}$

$\mathrm{B}(\mathrm{R})$

$\mathrm{B}(\mathrm{O})$

$\mathrm{B}(\mathrm{O})$

Meso

Meso

S,Er

S,Er

Meso

$\mathrm{S}, \mathrm{Er}$

F. (O);B (M) Hygro

$\mathrm{F}(\mathrm{O}) ; \mathrm{B}(\mathrm{M}) \quad$ Hygro

$\mathrm{F}(\mathrm{O}) ; \mathrm{B}(\mathrm{M}) \quad$ Hygro

$\mathrm{H}, \mathrm{Er}$

$\mathrm{H}, \mathrm{Er}$

$\mathrm{H}, \mathrm{Er}$

$\mathrm{B}(\mathrm{A}) ; \mathrm{D}(\mathrm{M})$

$B(M)$

Meso

Meso

$\mathrm{B}(\mathrm{O})$

Meso

Pr

$\operatorname{Pr}$

H, Er

I. pes-tigridis $\mathrm{L}$.

$\mathrm{B}(\mathrm{O})$

$\mathrm{B}(\mathrm{O})$

$\mathrm{B}(\mathrm{O})$

$\mathrm{B}(\mathrm{R})$

$\mathrm{B}(\mathrm{M})$
Meso

Meso

Meso

Meso

Meso
H, Er-As-Pr

$\mathrm{H}$,As

$\mathrm{H}$; Er

$\mathrm{H}, \mathrm{Er}$

H, Er

\begin{tabular}{lccc} 
An & F,B,D (O) & Hygro & $\mathrm{Cr}$ \\
An & $\mathrm{B}(\mathrm{O})$ & Meso & $\mathrm{Cl}$ \\
$\mathrm{An}$ & $\mathrm{B}(\mathrm{R})$ & Meso & $\mathrm{Cl}$ \\
\hline
\end{tabular}


Appendix 1 contd.

Group/Family/

Species
Life cycle $^{\mathrm{a}}$ Major habitat ${ }^{b} \&$ Habit $^{d} \quad$ Life-form $^{\text {e }}$ (Occurrence) $^{c}$

Rubiaceae

Borreria laevis (Lamk.)Griseb.

$\mathrm{Pe}$

$\mathrm{B}(\mathrm{M})$

Meso

Er, H

Hedyotis corymbosa (L.) Lamk.

An

$\mathrm{B}(\mathrm{M})$

Meso

Er, $\mathrm{H}$

Spermococe assungera $\mathrm{L}$.

An

$\mathrm{B}(\mathrm{O})$

Meso

Er, H

Lamiaceae

Basilicum polystachyon $\mathrm{L}$.

Leucas zeylanica (L.)R.Br.

An

$\mathrm{B}(\mathrm{M})$

Meso

Er, H

An

$\mathrm{B}(\mathrm{O})$

Meso

Er, $\mathrm{H}$

Amaranthaceae

Alternanthera sessilis

(L.) DC

$\mathrm{Pe}$

F,B,D (O)

Hygro

Cr

Mimosaceae

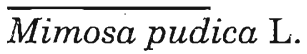

$\mathrm{Pe}$

$\mathrm{B}(\mathrm{O})$

Meso

$\mathrm{H}, \mathrm{As}-\mathrm{Pr}$

Sphenocleaceae

Sphenoclea zeylanica Gaerth.

An

$\mathrm{F}(\mathrm{M}), \mathrm{B}(\mathrm{R})$

Hygro

H, $\mathbb{E r}$

Elatinaceae

Elatine triandra Schkuhr.

An

F (A)

Hydro Cr, Sub

Apiaceae

$\overline{\text { Centella }}$ asiatica (L.) Urb.

$\mathrm{Pe}$

$\mathrm{B}, \mathrm{D}(\mathrm{O})$

Hygro

$\mathrm{Cr}$

Pterydophytes

Salviniaceae

Salvinia molesta D.S.Mitchell An (Pe)

$\mathrm{F}(\mathrm{A})$

Hydro

Fl, St

Marsiliaceae

Marsilia quadrifolia L. $\quad$ Pe $\quad$ F,B (A); D (O) Hygro Hygro


Appendix 2: Microflora and macrofungi, their life-forms and occurrence in the rice field ecosystem.

${ }^{\text {a }} \mathrm{Ff}=$ Free Floating; $\mathrm{Co}=$ Colonial $; \mathrm{At}=$ Attached $\mathrm{F}=$ Free; $\mathrm{Fi}=$ Filamentous $\mathrm{S}=$ Solitary $\mathrm{Ag}=$ Aggregate; $\mathrm{M}=$ Motile ${ }^{\mathrm{b}} \mathrm{C}=$ Common, $\mathrm{UC}=$ Uncommon

Phylum/Group/Gen
Cyanophyta (BGA)

Aphanothece Naegeli

$\mathrm{Co}, \mathrm{Ff}$

$\mathrm{C}$

Aphanocapsa Naegeli

Co, Ff

$\mathrm{UC}$

Anabaena Bory

$\mathrm{Fi}, \mathrm{Ff} / \mathrm{At}$

$\mathrm{C}$

Coelosphaerium Naegeli

Co, Ff

C

Merismopedia Meyen

$\mathrm{Co}, \mathrm{Ff}$

$\mathrm{UC}$

Microcyctis Kutzing

Co, $\mathrm{Ff}$

UC

Nostoc Vaucher

$\mathrm{Co}, \mathrm{At} / \mathrm{F}$

UC

Oscillatoria Vaucher

$\mathrm{Fi}$

Chlorophyta

\section{Filamentous algae}

Spirogyra Link

Fi, Ff

C

Flagellated forms

Volvox Linnaeus

$\mathrm{S}, \mathrm{Co}, \mathrm{M}$

UC

Gonium Mueller

$\mathrm{S}, \mathrm{Co}, \mathrm{M}$

UC

Chlamydomonas Ehrenberg

S, Co, M

C

\section{Desmids}

Ankistrodesmus Corda

$\mathrm{S} / \mathrm{Ag}, \mathrm{Ff}$

C

Cosmarium Corda

$\mathrm{S}, \mathrm{Ff}$

C

Closterium Nitzsch

$\mathrm{S}, \mathrm{Ff}$

UC

Docidium deBrebisson

$\mathrm{S}, \mathrm{Ff}$

UC

Euastrum Ehrenberg

$\mathrm{S}, \mathrm{Ff}$

C

Enteromorpha Link

Microspora Thuret

$\mathrm{Co}, \mathrm{Ff} / \mathrm{At}$

UC

Micrasterias Agardh

$\mathrm{Fi}, \mathrm{Ff}$

UC

$\mathrm{S}, \mathrm{Ff}$

$\mathrm{C}$

Netrium Naegeli

$\mathrm{S}, \mathrm{Ff}$

UC

Pleurotaenium Naegeli

$\mathrm{S}, \mathrm{Ff}$

$\mathrm{C}$

Penium deBrebisson

$\mathrm{S} / \mathrm{Ff}$

UC

Protosiphon Klebs

Co, At

UC 
Appendix 2 contd.

Phylum/Group/Genus

Pediastrum Meyen

Scenedesmus Meyen

Tetraedron Kuetzing

Euglenophyta

Euglena Ehrenberg

Phacus Dujardin

Bacillariophyta (Diatoms)

Frustulia

Navicula

Macrofungi

Agaricales

Agaricus spp.

Coprinus spp.

Lycoperdales

Lycoperdon
Life-form $^{a}$

Occurrence $^{b}$

Co, Ff

C

Co, Ff

UC

S, Ff

UC

S, M

C

S, M

C

UC

C

C

C

UC 


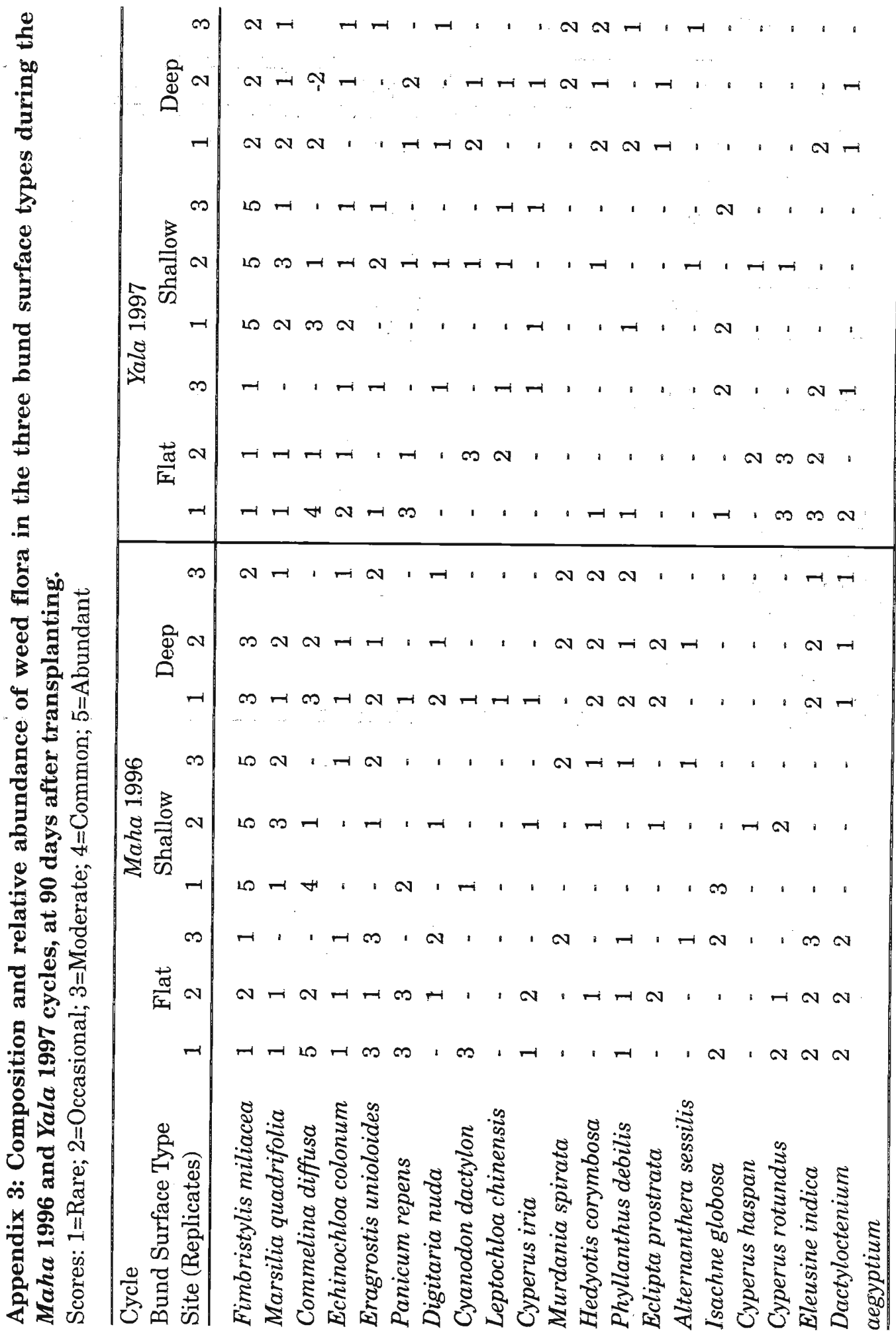




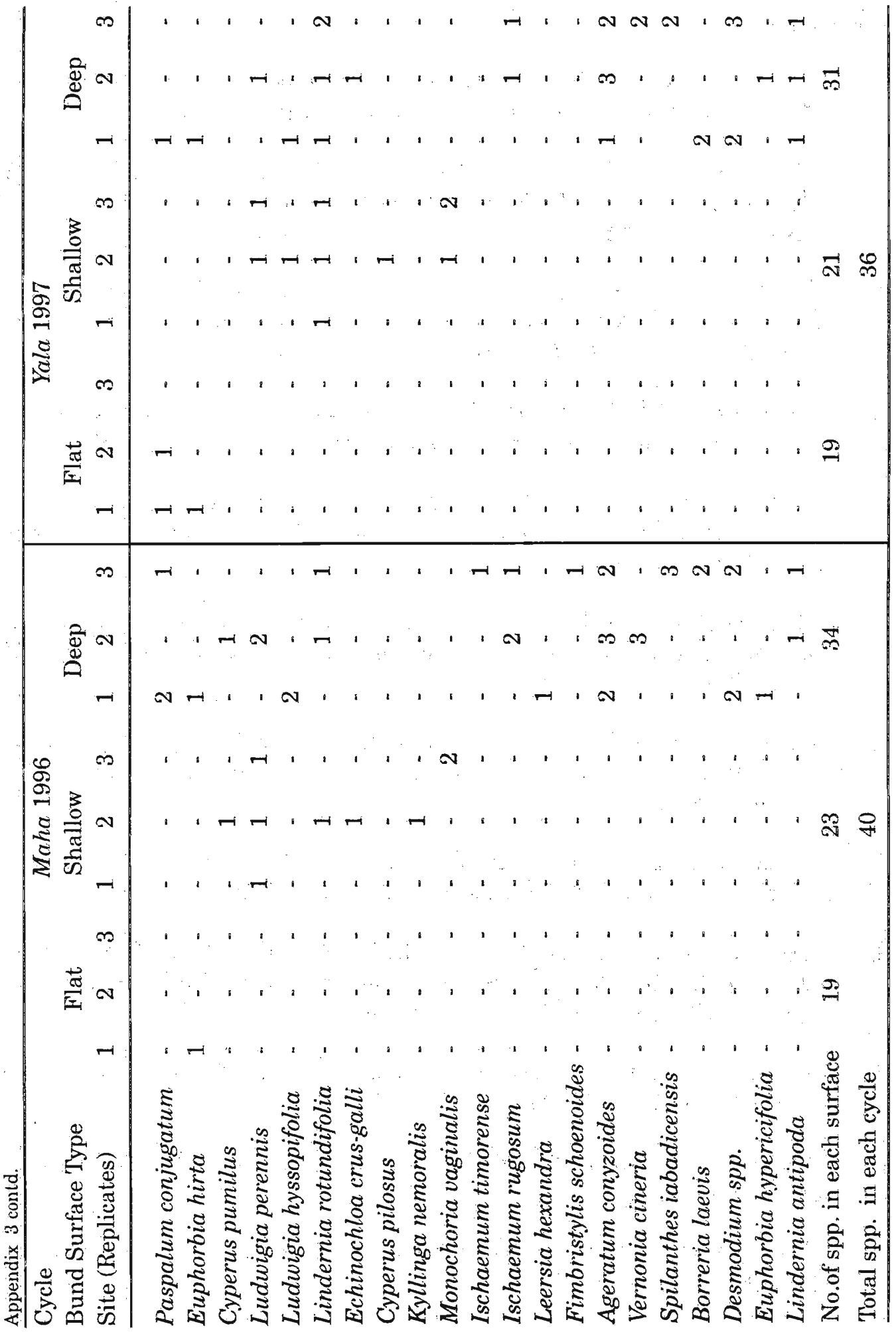




\section{References}

1 Abeywickrema B. A. (1979). The Genera of the freshwater algae of Sri Lanka. Part 1. Natural Resources, Energy \& Science Authority of Sri Lanka.

2 Abeywickrema B. A., Abeywickrema L., Arulgnanam P. \& Jansen M.A.B. (1986). The Genera of the freshwater algae of Sri Lanka. Part 11. Natural Resources, Energy \& Science Authority of Sri Lanka.

3 Ameratunge K. L. D. (1977). A provisional list of weeds (phanerogams) found in arable soils in Sri Lanka with special reference to three noteworthy new records. Ceylon J. Sci.,. 12 (2):185-193.

4 Chandrasena J. P. N. R. (1987). Rice-field weeds in the Colombo and Gampaha districts of Sri Lanka. J. Natn. Sci. Coun. Sri Lanka 15 (2): 249-265.

5 Chandrasena J. P. N. R. (1988). Floristic composition and abundance of ricefield weeds in four low-country wet zone districts of Sri Lanka. Tropical Pest Management., 34(3), 278-287.

6 Chandrasena J. P. N. R. (1989). A survey of the rice-field weeds in Ratnapura and Kurunegala districts of Sri Lanka. J. Natn. Sci. Coun., Sri Lanka., 17 (2):187-211.

7 Chandrasena J. P. N. R. (1990). An illustrated manual of rice field weeds in Sri Lanka. Natural Resources, Energy \& Science Authority of Sri Lanka, Colombo, 184pp.

8 Dassanayake M. D. \& Fosberg F.R. (eds.) (1980 - 1996). Revised handbook to the flora of Ceylon, Vols. I-X. Amerind Publ., New Delhi.

9 Halwart M. (1993). Fish in rice fields. In: P.P. Milan \& S. Margraf (eds.) Annals of tropical research. Special issue on ecology VISCA-GTZ ecology program. Philippine freshwater ecosystems.

10 Amerasinghe L. (1985). Rice weeds in minor tank paddy fields and their effects on crop yields. Krushi, 2:17-24.

11 Heckman C.W. (1979) Rice field ecology in North East Thailand. Monogr. Biol, 34: 228pp.

12 Magurran A. E.(1988). Ecological diversity and its measurement. Croom Helm Ltd, London. 
13 Moody K. (1989). Weeds reported in rice in South and Southeast Asia. IRRI, Los Banos, Philippines.

14 Pons T. L., Eussen J.H.H. \& Otomo I. H. (1987). Ecology of weeds of rice. In Soerjani M., Kostermans A. J. G. H. \& Tjitrosoepomo G. (eds.) Weeds of rice in Indonesia . Balai Pustaka, Jakarta, Indonesia.

15 Roger P. A. \& Kurihara Y. (1991). The floodwater biology of tropical wetland rice fields. In: Soil management for sustainable rice production in the tropics. International Board for Soil Research and Management (IBSRAM). Monograph 2: pp.211-233.

16 Seneviratne G., Kulasooriya S.A., Gunatilleke C.V.S. \& Rosswall T. (1992). Ecology of rice fallow vegetation under lowland traditional farming in the dry zone of Sri Lanka. Tropical Ecology., 31 (1): 17-28.

17 Smith R. J. (1983). Weeds of major economic importance in rice and yield losses due to weed competition. In: Proc. of the Conf. on Weed Control in Rice, International Rice Research Institute, Manila, Philippines, International Weed Science Society.

18 Soerjani, M., Kostermans A.J.G.H. \& Tjitrosoepomo G. (1987). Weeds of rice in Indonesia . Balai Pustaka, Jakarta, Indonesia.

19 Velmurugu V. (1980). A review of weed control in rice. In Proc. Rice symposium, Dept. of Agriculture, Sri Lanka, pp 109-132.

20 Weerakoon W. L. \& Gunewardena S.D.I.E. (1983). Rice field weed flora of Sri Lanka. Tropical Agriculturist., 139, 1-14.

21 Yamasue Y., \& Ueki W. (1983). Biology of paddy weeds and their control in wetland rice. In: Proc. of the Conf. on Weed Control in Rice, International Rice Research Institute, Manila, Philippines, International Weed Science Society, pages 227-242. 